\title{
EVALUATION OF CARTOSAT 1 PAN STEREO AND RESOURCESAT LISS 4 MSS MERGED DATA FOR MORPHOMETRIC ANALYSIS, DELINEATION OF DRAINAGE BASINS AND CODIFICATION IN TAMIL NADU, INDIA AND AUSTRALIA
}

\author{
Ghouse Shaik Mohamed ${ }^{1 *}$, Santhanaraman Srinivasan ${ }^{2}$, Rathinasabathy Pandian ${ }^{3 \#,}$ \\ Radhika Janakiraman Gummidipoondi ${ }^{4 \#}$, Ramakrishnan Venugopal Venkatchalam ${ }^{5 \#}$, Senthil Swaminathan.S ${ }^{6 \#}$ \\ ${ }^{1}$ Director Research,ghouse967@,hotmail.com,+919444055967,2Dean,sanramansmailbox@rediffmail.com, \\ ${ }^{\#}$ Asst Proff, ${ }^{3}$ prethinas@yahoo.com, ${ }^{4}$ mradhi.80@gmail.com, ${ }^{5}$ vvramkee2k@yahoo.co.in, ${ }^{6}$ senthilswami2005@gmail.com, \\ Sri Venkateswara college of Engineering and Technology, Thirupachur, Thiruvallur, \\ Anna University, Chennai, Tamil Nadu, India
}

Working Group: IV/3: Mapping from High Resolution Data

KEY WORDS: Cartosat, High Resolution satellite, Micro watershed, Dr A.N.Khosla codification of watersheds

\begin{abstract}
The Topographic maps and Aerial Photographs are used for morphometric analysis of drainage basins and mapping contours with drainage. The stereo pairs of $2.5 \mathrm{~m}$ resolution Cartosat 1 , Indian satellite ${ }^{2}$ and merged data with $5.5 \mathrm{~m}$ resolution P6 Resourcesat 1 LISS 4 Indian satellite of 2007 is used to map, rills, gullies and streams of first order to evaluate part of drainage basins of Cooum and Poondi Reservoir in Thiruvallur taluk of Tamil Nadu state. The Geo Eye latest 2011 data is also used with Cartosat 1 Stereo data to study present morphology of tiny micro watersheds to study the use of High resolution data for delineation and codification of watersheds. This study area is in an inter fluvial drainage basin of Cooum and Kusasthalai rivers. Kusasthalai river drains in Poondi reservoir which is about $50 \mathrm{Km}$ from Chennai. The excess water from Kosasthalai is also diverted through Kesawaram weir to Cooum river which passes through Thiruvallur and Chennai city before it's confluence with Bay of Bengal in the east. As Cooum basin is at higher elevation, water for irrigation is again diverted through chain of tanks to Kusasthalai river basin to drain in Poondi reservoir. Delineation of water sheds in this fluvial basin is difficult by manual survey as man made irrigation channels, natural drainage streams etc., have to be clearly identified. The streams of various orders are identified based on Strahler stream order hierarchy of tributaries, slops and contours using large scale satellite data. The micro water sheds are delineated identifying the ridges from Cartosat data for this interfluves basin which has mild slop. To illustrate this research, parts of two micro watersheds which were delineated using 1:50000 data for Tamil Nadu watershed Atlas up to $7^{\text {th }}$ order streams are taken up for a detailed study using high resolution data. 19 Micro watersheds with streams up to $10^{\text {th }}$ order are mapped. The capability of the high resolution satellite data for digital as well as visual interpretation in conjunction with village cadastral maps has been studied. This research will be useful to consider creation of digital micro watershed atlas for management and protecting area affected by floods as well as for water and land resource management of the River basins in Queensland, New South whales, South Australia and Victoria states of Australia. The research explains the need of using steam orders, delineation and codification micro watersheds based the principles of Dr.A.N.Khosla. This methodology was used in creation of web site of Districts soil water shed atlas of Tamil Nadu state. With this principal of codification and delineation of watersheds based on stream order using stereo data of Cartosat1 PAN $2.5 \mathrm{~m}$ data merged with Resourcesat LISS 4 data of $5.5 \mathrm{~m}$ resolution and updating latest changes as on 2011 with non stereo Geo eye data of $0.5 \mathrm{~m}$ resolution it is possible to create Australian micro water shed GIS with details of streams with various stream orders, drainage pattern, slope, micro water sheds boundary in 1:5000 scale to manage the flood prone drainage basin in Australia. The High resolution data of satellites data apart from creation Micro watershed GIS can be used for creation of Urban and Agricultural land parcel ownership details in Micro watershed GIS.
\end{abstract}

\section{INTRODUCTION:}

Aerial Photographs with Topographic maps are being used in 1:50000 scale for delineation of watersheds and study the geomorphology, estimation of run off and sediment yield to understand fluvial soil erosion. High resolution satellite data like Cartosat series from India, Geo Eye and Spot are available now. This research, evaluate the use of high resolution satellite data for delineation of micro water sheds using Dr A.N.Khosla's principles using high resolution satellite data for a micro watershed in Thiruvallur district in Tamil Nadu. The need for micro watershed codification in Australia with 1:10000/1:5000 scale is studied *Corresponding Author to have an accurate data base to understand geomorphology, hydrology and landforms using higher resolution data because high resolution data is now normally used for Urban planning or Agricultural Land parcels GIS.

\section{DR. A.N. KHOSLA'S WATER SHED CODIFICATION ADOPTED IN TAMIL NADU, INDIA}

India is delineated in to Six water resources regions as suggested by Dr. A.N. Khosla ${ }^{14}$ in 1949 by numbering them in clockwise direction. They are: 


\subsection{Water Resources Regions in India 15 Region Water resources Region Name \\ No \\ 1 Indus River Region \\ 2 Ganges River Region}

3 Brahmaputra River

Region

$4 \quad$ Region covering all east flowing rivers draining in Bengal except Ganges and Brahmaputra.

$5 \quad$ Region covering all rivers draining in Arabian sea in . . west.

$6 \quad$ Region covering the rivers having ephemeral . drainage in Rajasthan desert

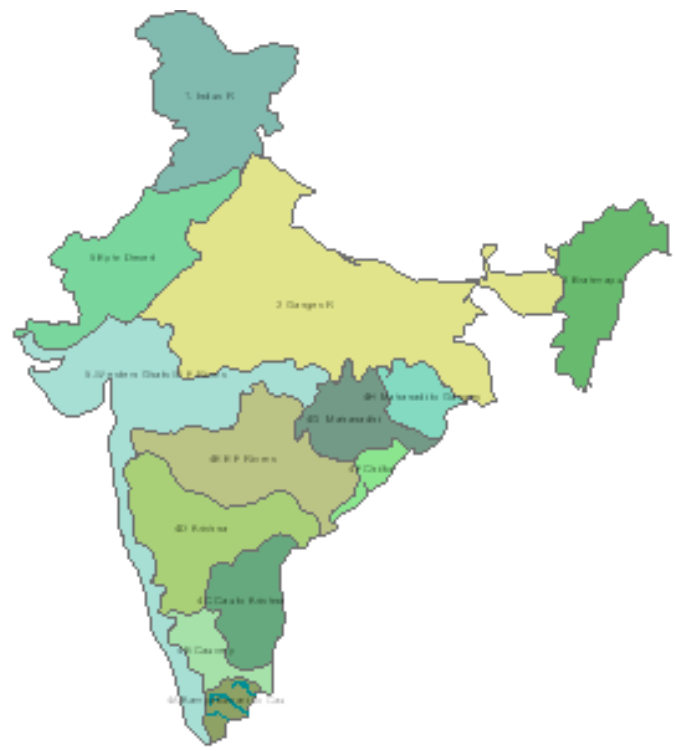

Figure.1. Water resources Regions in India ${ }^{10}$,

Based on these codifications water resources region 5 in Tamil Nadu and near by Kerala states is delineated in to $5 \mathrm{~A}$ basin which drain in Arabian sea and water resources region 4 in Tamil Nadu, Karnataka and Andhra Pradesh states in to $4 \mathrm{~A}, 4 \mathrm{~B}$ and $4 \mathrm{C}$ basins which drain in Bay of Bengal.( Table 1).

Table 1.River Basins in Tamil Nadu ${ }^{11}$

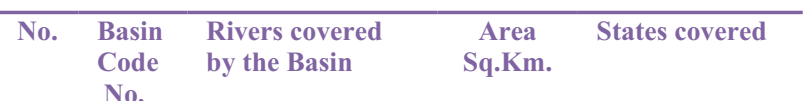

\begin{tabular}{|c|c|c|c|c|}
\hline 1 & $4 \mathrm{~A}$ & $\begin{array}{l}\text { All rivers draining } \\
\text { in Bay of Bengal } \\
\text { from Kanyakumari } \\
\text { Dist. below } \\
\text { Cauvery basin }\end{array}$ & 38,740 & $\begin{array}{l}\text { Tamil Nadu and } \\
\text { Kerala }\end{array}$ \\
\hline 2 & 4B & Cauvery & 72,000 & $\begin{array}{l}\text { Tamil Nadu, } \\
\text { Pondicherry, } \\
\text { Karnataka and } \\
\text { Kerala }\end{array}$ \\
\hline 3 & $4 \mathrm{C}$ & $\begin{array}{l}\text { All rivers draining } \\
\text { in Bay of Bengal } \\
\text { between Cauvery } \\
\text { and Krishna }\end{array}$ & 146,000 & $\begin{array}{l}\text { Tamil Nadu, } \\
\text { Karnataka, } \\
\text { Andhra Pradesh, } \\
\text { Pondichery }\end{array}$ \\
\hline
\end{tabular}

\begin{tabular}{llrl}
$45 \mathrm{~A} \quad \begin{array}{l}\text { All rivers draining } \\
\text { in Arabian Sea }\end{array}$ & $56,200 \quad \begin{array}{l}\text { Tamil Nadu, } \\
\\
\end{array}$ \\
& Kerala, \\
& Pondichery, and \\
& Karnataka \\
\hline
\end{tabular}

2.2.Relation ship of Micro Watershed with Stream order, Area \& Watershed Code No

The basins were further delineated in to Catchment, Sub Catchment and Watersheds. Tamil Nadu state has about 230 water sheds. The watershed is indicated using capital alphabets and numerals. The watersheds are further delineated in to next level as sub watersheds, mini watersheds, micro watersheds Gradel to Grade VII based on the geo morphological characteristic of streams in the soil watershed Atlas of Tamil Nadu which is now available in the web site http://www.aedatlas.tn.nic.in The codification of micro watersheds is done in the same pattern of A.N.Khosla with alternate small alphabets instead of capital letters and numerals. ( Table 2).

This Atlas removes the concept of delineation of water shed based on area etc. Earlier there was a practice of defining micro watersheds based on area. A watershed with 500 ha is termed as micro watershed without considering geomorphology. A micro water shed may be large covering 1000 ha in plains and small covering 100 ha to 10 ha in hills based on drainage pattern with the ridge of the micro watershed as the permanent natural boundary.

\section{MICRO WATERSHED}

\subsection{Micro watershed definition}

MICRO WATER SHED is defined as that one generally formed by second order streams because $1^{\text {st }}$ order streams are virgin drainage courses for water by fluvial erosion process of sheet, rill and gully erosion and the $1^{\text {st }}$ order stream is young and may not stabilized. This assumption also avoids the codification of very tiny watersheds in hills with dendritic or sub dendritic drainage pattern. Stream adopts generally parallel and sub parallel pattern in irrigated command areas and plains. The drainage or feeder channels from the lakes or rivers are considered as first or second order streams to evaluate and study stream morphology.

\subsection{Terminology ${ }^{10}$-Codification of watershed $4 \mathrm{C} 2 \mathrm{C} 4$}

The terminology of $4 \mathrm{C} 2 \mathrm{C} 4$ Kusasthalai watersheds and Poondi Reservoir -Ramancheri mini watershed $4 \mathrm{C} 2 \mathrm{C} 4 \mathrm{~b} 1$ is detailed below

$\begin{array}{ll}\text { Region : } & \text { 4 Rivers draining in Bay of Bengal } \\ \text { Basin: } & \text { C Between Cauvery and Krishna } \\ \text { Catchment: } & 2 \text { Between Pennaiyar and Pennar } \\ \text { Sub Catchment: } & \text { C Miscellaneous around Chennai } \\ \text { Watershed: } & 4 \text { Kosasthalai Aru } \\ \text { Sub Watershed: } & \text { b Ramanjeri } \\ \text { Mini watershed: } & \text { 1 Poondi Reservoir-Ramanjeri }\end{array}$

The correlation between code number of micro watersheds, their area and stream order is explained in Table No 2. The micro watershed in plains may have $9^{\text {th }}$ or lesser stream order. Where as at hilly region it may be above $14^{\text {th }}$ order as we can identify more streams while using high resolution satellite data and delineating micro water sheds. This precision in delineation is not feasible while using 1:50000 topo graphic sheets with about $22 \mathrm{~m}$ resolution data of Land sat , IRS LISS 3 or other satellites. 
Table 2. Correlation between watershed code numbers their area and stream orders. ${ }^{8}$

\begin{tabular}{|c|c|c|c|c|c|}
\hline No & $\begin{array}{c}\text { Watershed } \\
\text { Grade from } \\
\text { Region to micro } \\
\text { watershed }\end{array}$ & $\begin{array}{c}\text { Stre } \\
\text { am } \\
\text { Or } \\
\text { der } \\
\text { No. } \\
\text { in } \\
\text { Plai } \\
\text { ns }\end{array}$ & $\begin{array}{c}\text { Stre } \\
\text { am } \\
\text { or } \\
\text { der } \\
\text { No. } \\
\text { in } \\
\text { Hills } \\
\text { and } \\
\text { upla } \\
\text { nds }\end{array}$ & $\begin{array}{l}\text { App. Area } \\
\text { in sq. } \mathrm{km} .\end{array}$ & $\begin{array}{l}\text { Watershe } \\
\text { d Code }\end{array}$ \\
\hline 1 & Region & & & & 4 \\
\hline 2 & Basin & 8 & 11 & $\begin{array}{c}500000 \\
\text { and above }\end{array}$ & $4 \mathrm{C}$ \\
\hline 3 & Catchment & 7 & 10 & $\begin{array}{c}500000 \text { to } \\
100000\end{array}$ & $4 \mathrm{C} 2$ \\
\hline 4 & Sub Catchment & 6 & 9 & $\begin{array}{c}100000 \text { to } \\
5000\end{array}$ & $4 \mathrm{C} 2 \mathrm{C}$ \\
\hline 5 & Watershed & 5 & 8 & $\begin{array}{c}5000 \text { to } \\
1000\end{array}$ & $4 \mathrm{C} 2 \mathrm{C} 4$ \\
\hline 6 & Sub Watershed & 4 & 7 & $\begin{array}{c}1000 \text { to } \\
500\end{array}$ & $4 \mathrm{C} 2 \mathrm{C} 4 \mathrm{~b}$ \\
\hline 7 & Mini Watershed & 3 & 6 & $\begin{array}{c}500 \text { to } \\
200\end{array}$ & $\begin{array}{c}4 \mathrm{C} 2 \mathrm{C} 4 \\
\mathrm{~b} 1\end{array}$ \\
\hline 8 & $\begin{array}{l}\text { Micro } \\
\text { watershed gr } 1\end{array}$ & 2 & 5 & $\begin{array}{c}200 \text { to } \\
100\end{array}$ & $\begin{array}{c}4 \mathrm{C} 2 \mathrm{C} 4 \\
\mathrm{~b} 1 \mathrm{a}\end{array}$ \\
\hline 9 & $\begin{array}{l}\text { Micro } \\
\text { watershed gr } 2\end{array}$ & 1 & 4 & 100 to 50 & $\begin{array}{c}4 \mathrm{C} 2 \mathrm{C} 4 \\
\mathrm{~b} 1 \mathrm{a} 1\end{array}$ \\
\hline 10 & $\begin{array}{l}\text { Micro } \\
\text { watershed gr } 3\end{array}$ & & 3 & 50 to 10 & $\begin{array}{l}4 \mathrm{C} 2 \mathrm{C} 4 \\
\mathrm{~b} 1 \mathrm{a} 1 \mathrm{c}\end{array}$ \\
\hline 11 & $\begin{array}{l}\text { Micro } \\
\text { watershed gr } 4\end{array}$ & & 2 & 10 to 5 & $\begin{array}{l}4 \mathrm{C} 2 \mathrm{C} 4 \\
\mathrm{~b} 1 \mathrm{a} 1 \mathrm{c} 1\end{array}$ \\
\hline 12 & $\begin{array}{l}\text { Micro } \\
\text { watershed gr } 5\end{array}$ & & 1 & 5 to 1 & $\begin{array}{c}4 \mathrm{C} 2 \mathrm{C} 4 \\
\text { b1a1 c1a }\end{array}$ \\
\hline
\end{tabular}

Table 3. The code no of five watersheds in study area ${ }^{11}$.

\begin{tabular}{|c|c|c|c|}
\hline $\begin{array}{l}\text { S1 } \\
\text { N } \\
\text { o. }\end{array}$ & $\begin{array}{l}\text { Watershed } \\
\text { Code No }\end{array}$ & $\begin{array}{l}\text { Area } \\
\text { sq km }\end{array}$ & Rev No, Village and Reserve Forest \\
\hline 1 & $\begin{array}{l}4 \mathrm{C} 2 \mathrm{C} 4 \\
\mathrm{~b} 2 \mathrm{a} 1 \mathrm{a}\end{array}$ & 8.58 & $\begin{array}{l}\text { 117.Tiruppair, Nayappakkam R.F., } \\
\text { 125. Poondi, } \\
\text { Pullarampakkan Extn.R.F., }\end{array}$ \\
\hline 2 & $\begin{array}{l}4 \mathrm{C} 2 \mathrm{C} 4 \\
\mathrm{~b} 2 \mathrm{a} 1 \mathrm{~b}\end{array}$ & 12.33 & $\begin{array}{l}\text { 114. Sengampalayam, Allikuli R.F., } \\
\text { 118. Ramanjeri }\end{array}$ \\
\hline 3 & $\begin{array}{l}4 \mathrm{C} 2 \mathrm{C} 4 \\
\mathrm{~b} 2 \mathrm{a} 1 \mathrm{c}\end{array}$ & 6.26 & $\begin{array}{l}\text { 116. Thombur, Allikuli R.F. } \\
\text { 115. Greenwaynatham, }\end{array}$ \\
\hline 4 & $\begin{array}{l}4 \mathrm{C} 2 \mathrm{C} 4 \\
\mathrm{~b} 2 \mathrm{a} 1 \mathrm{~d} 1\end{array}$ & 8.10 & 118. Ramanjeri \& Poondi Reservoir \\
\hline 5 & $\begin{array}{l}4 \mathrm{C} 2 \mathrm{C} 4 \\
\mathrm{~b} 2 \mathrm{a} 1 \mathrm{~d} 2\end{array}$ & 10.70 & 85. Kanchipadi, 118. Ramanjeri \\
\hline & $\begin{array}{l}\text { Total area sq } \\
\mathrm{km}\end{array}$ & 45.96 & \\
\hline
\end{tabular}

\section{DELINEATION OF MICRO WATER SHEDS USING 1:50000 MAP/SATELLITE DATA.}

The map of Poondi Ramancheri mini watershed in Thiruvallur district (Fig 2 ) and the Map of five micro watersheds of this Poondi Ramancheri watersheds ( Fig.3) are used to study the need of high resolution data to create GIS data base of micro watersheds.

\subsection{High Resolution satellite data for morph metric analysis}

The Indian Remote sensing satellite Cartosat 1, with $2.8 \mathrm{~m}$ resolution stereo, PAN data dated 27 ${ }^{\text {th }}$ March 2007 merged with Liss 4, $5.8 \mathrm{~m}$, Resolution multi spectral data dated 11 Jan 2005 is given in Fig 5 which is used to delineate field boundaries, drainage channels and streams. The Geo Eye image of Feb 2011 (Fig 4)from Google Earth web site is used to up date maps from Cartosat 12007 data. Arc GIS 10 and Leica Photogrammetry Suite were used for analysis in this study.

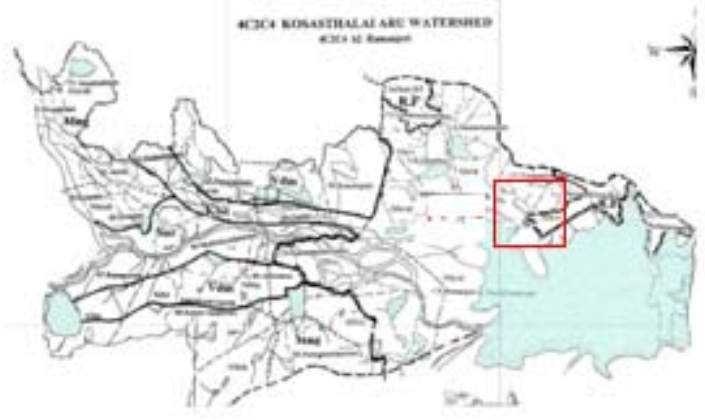

Figure 2. Poondi Reservoir -Ramancheri Mini Watershed4C2C4b1 ${ }^{11}$

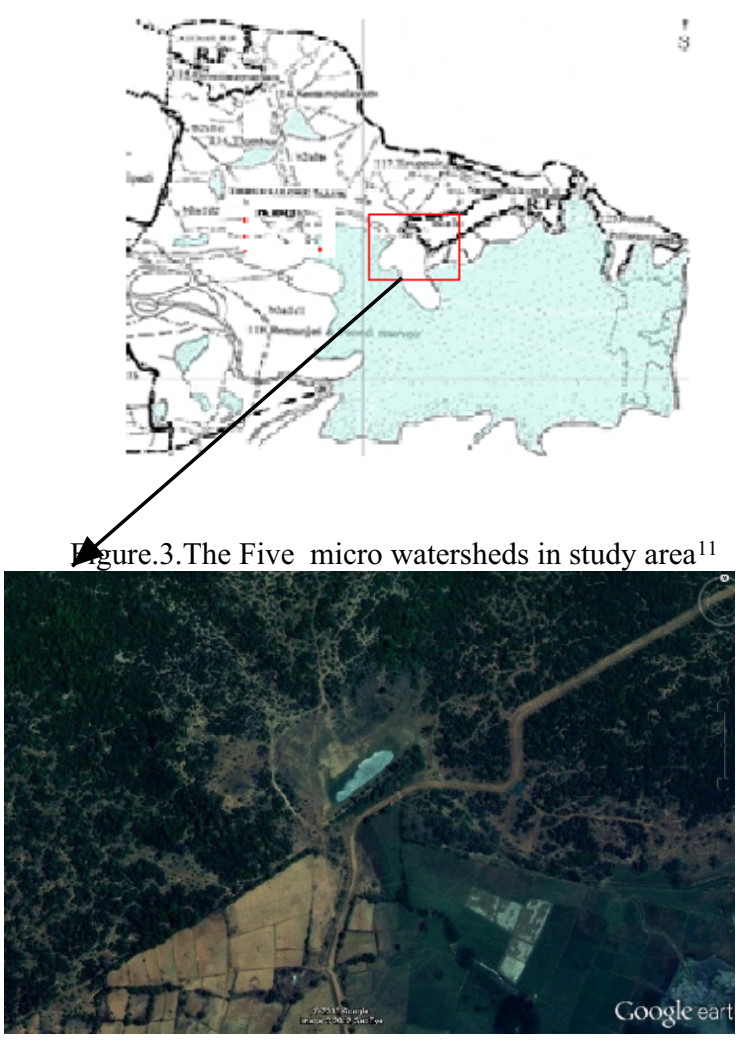

Figure. 4 High resolution data of area selected for analysis ${ }^{12}$

\section{ANALYSIS}

Parts of micro watersheds $4 \mathrm{C} 2 \mathrm{C} 4 \mathrm{~b} 2 \mathrm{a} 1 \mathrm{a}$ and $4 \mathrm{C} 2 \mathrm{C} 4$ b2a1b in 4C2C4 Poondi Reservoir Ramancheri watershed, are studied for using $^{3}$ Cartosat 1 and recent Google Earth image of 2011 to explain the research methodology. Delineation of water sheds in this fluvial basin is difficult by manual survey as the man made irrigation channels, natural drainage channels have to be clearly identified. The fig 
below details the drainage pattern in fluvial basin.

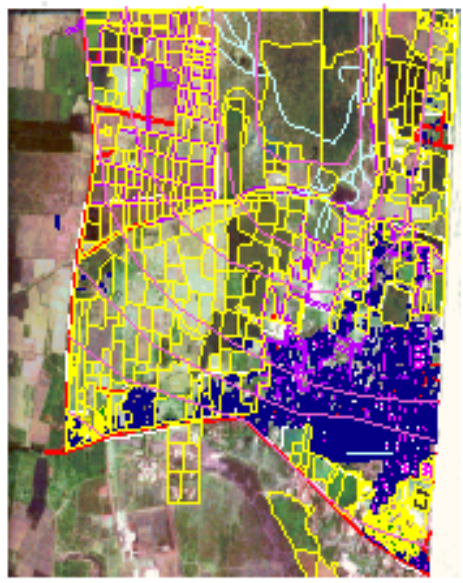

Figure 5.Cartosat 1,2.8 m resolution stereo PAN data merged with LISS IV MSS Resource sat satellite data ${ }^{5}$

The micro drainage is mapped from high resolution stereo satellite data and Pan and MSS merged data which is in colour. Streams in various orders are identified ${ }^{4}$. The contours from Cartosat 1 data enabled us to delineate water shed boundaries and identify the slope to map the area. The forest area has dendritic pattern and agricultural lands has sub parallel flow. The drainage channels from lakes are mapped to complete the drainage net work which could not have been done with 1:50000 map or $22 \mathrm{~m}$ resolution images.

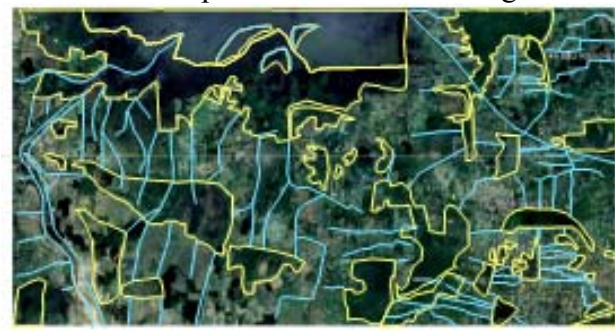

Figure 6. The drainage pattern in micro watersheds in irrigated tank command area mapped by using High Resolution satellite data in Kusasthalai fluvial watershed near Poondi reservoir ${ }^{12}$.The table below gives the details of additional micro watersheds and stream orders identified. The images of study area with micro watershed codes, stream order etc are given here to explain the out come of this study

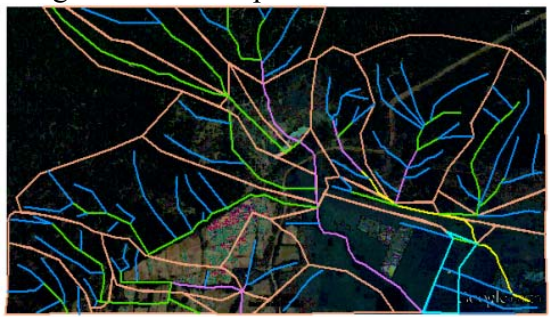

Figure 7 Stream order 1 to 4 in study area

Table4. The additional watersheds and streams while using high resolution data. ${ }^{1}$

\begin{tabular}{llcccc}
\hline No & Wastershed & & Code & Stream & Stream \\
& Terminolgy Based & on & No & order & order \\
Geomorphology & & & with & $1: 5000$ \\
& & & $1: 50000$ & image \\
\hline
\end{tabular}

\begin{tabular}{lllll}
\hline & & \multicolumn{3}{c}{ image } \\
\hline $\mathbf{1}$ & Region & 4 & & 11 \\
$\mathbf{2}$ & Basin & $\mathrm{C}$ & 7 & 10 \\
$\mathbf{3}$ & Catchment & 2 & 6 & 9 \\
$\mathbf{4}$ & Sub Catchnent & $\mathrm{C}$ & 5 & 8 \\
$\mathbf{5}$ & Watershed & $\mathrm{b}$ & 4 & 7 \\
$\mathbf{6}$ & Sub Watershed & 2 & 3 & 6 \\
$\mathbf{7}$ & Mini watershed & $\mathrm{a}$ & 2 & 5 \\
$\mathbf{8}$ & Micro watershed Gr 1 & 1 & 1 & 4 \\
$\mathbf{9}$ & Micro watershed Gr 2 & $\mathrm{a}$ & & 3 \\
$\mathbf{1 0}$ & Micro watershed Gr 3 & 2 & & 2 \\
$\mathbf{1 1}$ & Micro watershed Gr 4 & $\mathrm{a}$ & & 1 \\
$\mathbf{1 2}$ & Micro watershed Gr 5 & 2 & & \\
\hline
\end{tabular}

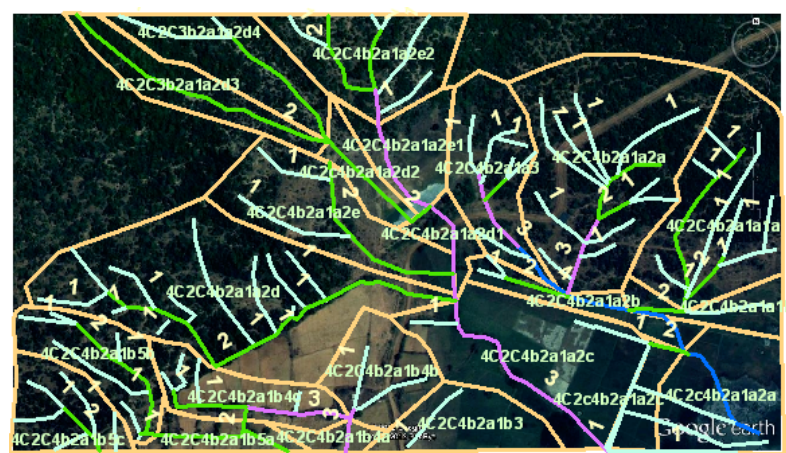

Figure 8 . The micro waterseds with code nos of study area.

The watereseds are given $\mathrm{m} 1$ to $\mathrm{m} 4$ grade ${ }^{6}$ based to explain the relationship with stream order in micro watershed. There are $\mathrm{m} 1$ micro watersheds with first order

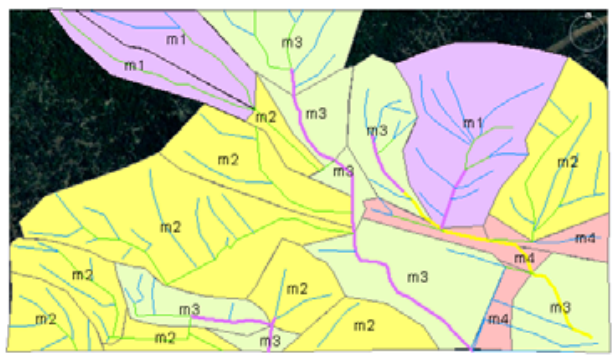

Figure.9. $\mathrm{m} 1$ to $\mathrm{m} 4$ grades of micro waterseds

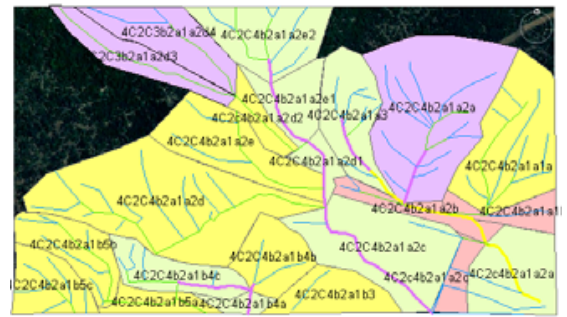

Figure 10. Micro watersheds with code nos. $\mathrm{m} 2$ watersheds with second order streams, $\mathrm{m} 3$ watersheds with $3^{\text {rd }}$ order stream and $\mathrm{m} 4$ watersheds with $4^{\text {th }}$ order streams as detailed in Fig 9. The figure 10 details the micro water sheds with their code Numbers 7 .

\section{WATERSHED CODIFICATION FOR AUSTRALIA}

The Australian major river map in Fig 11 indicates the rivers with nos from 1 to 57. If Dr A.N.Khosla's ${ }^{15}$ principals are adopted the south flowing rivers in South sea including Western Plateu ephemeral drainage draining in South sea and classified as Region1. Region 2 will comprise of east flowing rivers draining in Pacifica and Australian seas 
in East. Region 3 will covers North flowing rivers draining in Timour bay, Indian Ocean bays in north and Region 4 will have all west flowing rivers daring in Indian Ocean. With this map ${ }^{13}$ it is possible to indicate only delineation and codification up to basin/catchment level. The tables details the basin codefor the 57 Rivers.

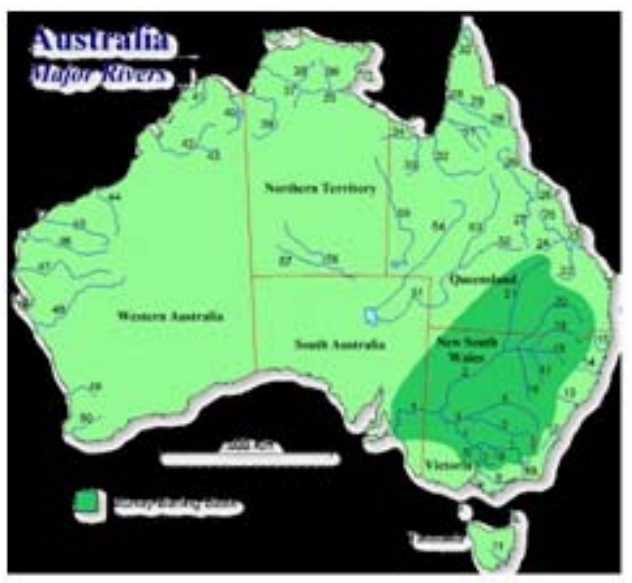

Figure 11.Australian Major Rivers

Table 4. Region 1.South sea flowing rivers, Murrey Darling river and other rivers basins

\begin{tabular}{|c|c|c|c|}
\hline $\begin{array}{l}\mathrm{R} \\
\mathrm{i} \\
\mathrm{v} \\
\mathrm{e} \\
\mathrm{r} \\
\mathrm{N} \\
\mathrm{O}\end{array}$ & River & Basin & $\begin{array}{l}\text { Watershed } \\
\text { / } \\
\text { Catchment } \\
\text { /Sub } \\
\text { catchment } \\
\text { Code }\end{array}$ \\
\hline 1 & Snowy & Snowy & $1 \mathrm{~A} 1$ \\
\hline 2 & Shoalhaven & Snowy & $1 \mathrm{~A} 2$ \\
\hline 3 & Hunter & Snowy & $1 \mathrm{~A} 3$ \\
\hline 4 & Macleay & Snowy & $1 \mathrm{~A} 4$ \\
\hline 5 & Clarence & Snowy & $1 \mathrm{~A} 5$ \\
\hline 6 & Murray & Murrey-Darling & $1 \mathrm{~B} 1$ \\
\hline 7 & Bogan & Murrey-Darling & $1 \mathrm{~B} 1 \mathrm{~A}$ \\
\hline 8 & Darling & Murrey-Darling & $1 \mathrm{~B} 2$ \\
\hline 9 & Macquarie & Murrey-Darling & $1 \mathrm{~B} 2$ \\
\hline 10 & Namoi & Murrey-Darling & $1 \mathrm{~B} 3$ \\
\hline 11 & Murrumbidgee & Murrey-Darling & $1 \mathrm{~B} 3 \mathrm{~A}$ \\
\hline 12 & Lachlan & Murrey-Darling & $1 \mathrm{~B} 3 \mathrm{~B}$ \\
\hline 13 & Campaspe & Murrey-Darling & $1 \mathrm{~B} 3 \mathrm{C}$ \\
\hline 14 & Goulburn & Murrey-Darling & $1 \mathrm{~B} 3 \mathrm{E}$ \\
\hline 15 & Barwon & Murrey-Darling & $1 \mathrm{~B} 4$ \\
\hline 16 & Condamine & Murrey-Darling & $1 \mathrm{~B} 5$ \\
\hline 17 & Warrego & Murrey-Darling & $1 \mathrm{~B} 6$ \\
\hline 18 & Yarra & Yarra & $1 \mathrm{C} 1$ \\
\hline 19 & Latrobe & Yarra & $1 \mathrm{C} 2$ \\
\hline 20 & Derwent & Hobart & $1 \mathrm{D} 1$ \\
\hline 21 & Goulburn & Murrey-Darling & 1B3D \\
\hline
\end{tabular}

\begin{tabular}{|l|l|l|c|}
\hline \multicolumn{3}{|c|}{ Region 2.East flowing Rivers draining in Pacific seas } \\
and bays-Australia \\
\hline 22 & Dawson & Fitzroy & 2 B2 \\
\hline 23 & Fitzroy & Fitzroy & 2 B1 \\
\hline 24 & Mackenzie & Fitzroy & 2 B3 \\
\hline 25 & Isaac & Fitzroy & 2B4 \\
\hline 26 & Burdekin & Burdekin & 2 C1 \\
\hline 27 & Suttor & Burdekin & 2 C 2 \\
\hline
\end{tabular}

Region 3.North flowing Rivers in Bays of Indian Ocean- Gulf of Carpentaria -Australia

\begin{tabular}{|l|l|l|c|}
\hline 28 & Mitchell & Alice & 3B1 \\
\hline 29 & Alice & Alice & 3 B2 \\
\hline 30 & Jardine & Alice & 3 A1 \\
\hline 31 & Staaten & Flinders & 3 A2A \\
\hline 32 & Flinders & Flinders & 3 A2B \\
\hline 33 & Leichhardt & Flinders & 3B1A \\
\hline 34 & Nicholson & Flinders & 3B1B \\
\hline 35 & Roper & Flinders & 3B2A \\
\hline 36 & Wilton & Flinders & 3 B2B \\
\hline 37 & Daly & Daly & 3C1A \\
\hline 38 & Katherine & Daly & 3 D1 \\
\hline 39 & Victoria & Victoria & 3 D2 \\
\hline 40 & Ord & Victoria & Oct \\
\hline & &
\end{tabular}

Region 4. West flowing Rivers Draining in Indian Ocean

\begin{tabular}{|l|l|l|c|}
\hline 41 & Drysdale & North West & 4 A1 \\
\hline 42 & Fitzroy & North West & 4 A2 \\
\hline 43 & Margaret & North West & 4 A3 \\
\hline 44 & De Grey & West & 4 A4 \\
\hline 45 & Fortescue & West & 4 A5 \\
\hline 46 & Ashburton & West & 4 A6 \\
\hline 47 & Gascoyne & West & 4B1 \\
\hline 48 & Murchison & West & 4B3 \\
\hline 49 & Swan/Avon & South West & 4 B4 \\
\hline 50 & Blackwood & South West & \\
\hline
\end{tabular}

Region 5. Western Plateau Ephemeral drainage draining in south sea during floods- Australia

\begin{tabular}{|l|l|l|c|}
\hline 51 & $\begin{array}{l}\text { Coopers } \\
\text { Creek }\end{array}$ & South Sea & 5A1 \\
\hline 52 & Barcoo & South Sea & 5A2 \\
\hline 53 & Thompson & South Sea & $5 \mathrm{~A} 3$ \\
\hline 54 & Diamantina & South Sea & $5 \mathrm{~A} 4$ \\
\hline 55 & Georgina & South Sea & 5A5 \\
\hline 56 & Finke & South Sea & 5A6 \\
\hline 57 & Palmer & South Sea & 5A7 \\
\hline
\end{tabular}

\subsection{Further scope of this research}

The code Nos of 57 basins in 5 Regions are given above. If codification and stream order GIS is created in 1:5000 scale with high resolution stereo data of Cartosat 1 updating with non stereo latest data from Geo Eye data with $0.5 \mathrm{~m}$ resolution the Micro watershed GIS it will be a Hydrological and Geomorphological data base treasure for Federal and State Govts of Australia to manage land and water resources. 


\section{RESULTS}

The capability of the high resolution satellite data for digital and visual interpretation in conjunction with village cadastral maps is studied. This research provides useful information for creation of digital micro watershed atlas for management and protecting the area which has number of tanks and river channels for irrigation which will be flooding during high rainfall.

Cartosat satellite stereo and LISS IV merged data is expected to have it's intensive use in water and land resource management for creation of GIS of micro watersheds in fluvial and aeolian basins.

The need of using steam orders, micro water sheds and their codification based on codification principles of Dr.A.N.Khosla from the water shed atlas web site of Tamil Nadu is studied in detail for further research in Australia.

Australia may also consider for delineation and codification of the watersheds using high resolution stereo satellite data to map streams of $14^{\text {th }}$ and higher orders.

The availability of 2.5 to $0.5 \mathrm{~m}$ high resolution data makes morphometric and hydrological analysis with less dependence on mathematical or regression models which has been in use as all data base is in 1:50000 scale.

If micro water shed codification is adopted it will enable the water resources managers to use common code no for watersheds in all states.

The practice of states adopting a list of 500 and above rivers only with name may be avoided.

The codification based on drainage pattern will give details on location of the streams. Use of same streams names for watersheds will avoid confusion in identification of watersheds.

The micro watershed code nos may become Federal ID for the streams in GIS data base and can be used by federal and state Governments to fund, monitor and management land and water resources projects as done in Tamil nadu India.

If Australia starts using GIS of Micro watersheds based on Stereo satellite data it will open a new avenue for research as micro information on land forms and watershed hydrology. Accurate information from Micro watershed GIS will be available to manage the land and water issues.

\section{Acknowledgement}

Indian Remote sensing centre ,Department of space India and Google web site, National informatics centre, Chennai, Govt of India, for the use of high resolution satellite data and the web sites

\section{References}

\section{Publications}

1.Mohamed Ghouse.S,RamakrishnanVV, Radika JG,

Santhanaraman.S et al 2012 May, Watershed Codification in

Canada ,GSDI 13, Quebec Canada

2.Mohamed Ghouse.S, Murthy RLN 2010 Indian Remote sensing satellite data for Greening Perth City Australia : $15^{\text {th }}$ ARSPC Alice Springs Australia

3.Mohamed Ghouse.S, Murthy RLN 2008 Cartosat Stereo Data for Water shed and Water resources GIS, 14tth ARSPC Darwin Australia
4.Mohamed Ghouse.S,Kuamr.D,Sukumar 2008 Tsunami 2004 and disaster management using High resolution IKNOS satellite Data AIT Bangkok

5.Mohamed Ghouse.S.,RamakrishnanVV, Radika GJ, 2009 Health GIS of Thiruvallur using LISS IV and Cartosat 1 merged data at Hyderabad India

6.Mohamed Ghouse.S, Murthy RLN 2007 Micro water shed terrain model of micro watershed near Canberra using Cartosat 1 Stereo Data Hobart, Australia

7.Mohamed Ghouse.S, and et al 2002 Asian Remote sensing Conference Watershed management system for Western ghats Singapore

8.Mohamed Ghouse and et al -1999- Golden jublee International Conference Soil Conservation society - Micro Water shed GIS and Codification in Tamil Nadu New Delhi

Books

9.Hand book of Applied Hydrology, Ven Te Chow, L.ib Congress GB661 C56

10.Watershed Atlas of India CGWB India

Web sites

11.http://www.aedatlas.tn.nic.in/

12.http://www.google.com/earth.html

13.http://www.nativefish.asn.au/ozrivers.html 14.http//

slusi.dacnet.nic.in/dwainew.html.

15.http://cgwb.gov.in/watershed/about-ws.html. 
International Archives of the Photogrammetry, Remote Sensing and Spatial Information Sciences, Volume XXXIX-B4, 2012 XXII ISPRS Congress, 25 August - 01 September 2012, Melbourne, Australia

Revised on 2.6.2012 